\title{
Welfare Analysis of Onion Farming Business in Moyo Hilir District, Sumbawa Regency
}

\author{
Sri Rahayu ${ }^{1, *}$ \\ ${ }^{1}$ Department of Development Economics, Samawa University, Sumbawa, Indonesia \\ *Corresponding author. E-mail: rahmaayu272@gmail.com
}

\begin{abstract}
High consumption of shallots makes this commodity has advantages and benefits for shallot entrepreneurs. Although the data shows that the productivity of shallots in Sumbawa Regency is quite high, in Serading village located in Moyo Hilir Subdistrict, Sumbawa Regency, most of the population earns a living as shallot farmers, but the welfare and income conditions are still relatively low. The purpose of this study was to analyze the welfare of shallot farming in Serading Village. This study uses a quantitative approach with causal associative research which aims to determine the relationship between two or more variables, causal relationships, using primary data, namely data obtained directly from the object of research. The technique of collecting data is through observation, interviews, documentation and using questionnaires. Secondary data in this study is data on the number of shallot farmers as many as 53 shallot farmers in Serading Village. The data analysis technique used is hypothesis testing. The results showed that the land area factor had a positive effect on the welfare of shallot farmers, with a significant value of 0.012 which was stated to be smaller than $0.05(0.012<0.05)$. The area of agricultural land is a determinant of the influence of agricultural commodities. The total land area in Serading Village is 460 hectares. In a year, shallot farmers harvest 2 times in the 3rd month and 9th month in the dry season because the age of the shallots at 1 harvest is a minimum of 65 days and a maximum of 70 days.
\end{abstract}

Keywords: Farming, Shallots, Welfare.

\section{INTRODUCTION}

The agricultural sector has contributed greatly to the development of the Indonesian economy. The agricultural sector is a very important sector in shaping the Gross Domestic Product. More than 50 percent of national income is generated from the agricultural sector. The role of the agricultural sector is as a source of producing basic necessities, clothing and housing, providing employment, contributing to high national income, and providing foreign exchange for the State. Economic growth and welfare of farmers depend on the level of income of farmers and the profits derived from the agricultural sector. Agriculture can also be the basis for developing rural economic activities through the development of agriculture-based businesses, namely agribusiness and agro-industry.

The level of welfare is a concept used to express the quality of life of people in an area at a certain time. The concept of welfare that is owned is relative, depending on the assessment of each individual community towards welfare. Welfare can be objectively seen from the factual conditions of the community's quality of life. Meanwhile, subjective well-being is measured by a person's level of satisfaction with their physical and economic conditions, such as the ability to meet daily needs and the condition of social relations in the surrounding environment.

Shallots are one of the vegetable commodity horticultural crops that grow well in the lowlands. The high level of demand and need for consumption of shallots makes this commodity has advantages and benefits for shallot entrepreneurs. The consumption of shallots in Indonesia per capita per year reaches 4.56 kilograms or 0.38 kilograms per capita per month. The high demand for shallots that continues to increase does not only occur in the domestic market, but also has the opportunity for export (Central Bureau of Statistics and Directorate General of Horticulture, 2017).

The highest production of shallots is in Sumbawa Regency, located in Pelampang, Moyo Hilir and Unter Iwes Districts. The large area of land in the three subdistricts results in large shallot productivity. Land area, productivity and production of shallots in Sumbawa Regency can be seen in the following table. 
Table 1. Harvested Area, Productivity and Production of Shallots in Sumbawa Regency broken down by District

\begin{tabular}{|l|c|c|c|}
\multirow{2}{*}{\multicolumn{2}{c|}{ Name }} & \multicolumn{2}{c|}{ Districts } \\
\cline { 2 - 4 } & Pelampang & Moyo Downstream & Unter Iwes \\
\hline Harvest Area $(\mathrm{Ha})$ & 2510 & 460 & 95.83 \\
\hline Productivity $(\mathrm{Kw} / \mathrm{H})$ & 95.69 & 95.43 & 1600,70 \\
\hline Production (Tons) & 24019.20 & 4389,80 & \\
\hline
\end{tabular}

Source: Central Bureau of Statistics

Although the data shows that the productivity of shallots in Sumbawa Regency is quite high, in Serading village, located in Moyo Hilir Subdistrict, Sumbawa Regency, most of the population make a living as shallot farmers, but the welfare and income conditions are still relatively low. This is caused by several factors, namely, the low selling price factor and high production costs. The selling price often decreases which causes shallot farmers in Serading village to experience losses after the shallot harvest. Meanwhile, the production costs they spend are not small, such as the cost of fertilizer, the cost of seeds, the cost of pesticides and other costs needed during the process of growing shallots.

The limited capital owned by shallot farmers in Serading village and an unprofessional workforce in the shallot production process also led to a decrease in the income of shallot farmers in Serading village, Moyo Hilir sub-district. Suratiyah (2015), explains that farmers' income is influenced by internal factors and external factors. The internal factors such as the age factor, the education factor and the land area factor, while the external factors are the availability of production facilities and prices. The high production potential of shallots needs to be balanced with land area, production costs, production quantities and selling prices that do not harm farmers.

\section{METHOD}

This study uses a quantitative approach with the type of causal associative research which aims to determine the relationship between two or more variables, a causal relationship, one of the independent variables affects the dependent variable (Sugiyono, 2016). The data used in this study is primary data, namely data obtained directly from the object of research. The data collection techniques are through observation, interviews, documentation and using questionnaires (Sugiyono, 2015). Secondary data in this study is data on the number of shallot farmers in Serading Village, Moyo Hilir District, Sumbawa Regency, as many as 53 shallot farmers. The data analysis technique used is hypothesis testing.

\section{RESULTS \& DISCUSSION}

Table 2. shows that the obtained tcount value of 1.021 with a significant level of 5\% (0.05) two-way test at degrees of freedom $\mathrm{df}=48$ is 0.284 , so tcount $>$ ttable $(1.021>0.284)$. It can be concluded that the factor of land area has a positive effect on the welfare of shallot farmers, with a significant value of 0.012 which is stated to be smaller than $0.05(0.012<0.05)$. From these results it can be concluded that the factor of land area has a significant influence on the welfare of shallot farmers. The production cost factor has a positive effect on the welfare of shallot farmers, with a significant value of 0.024 which is stated to be smaller than $0.05(0.024<0.05)$. It can be concluded that the production cost factor has a significant influence on the welfare of shallot farmers. The selling price factor also has a significant positive effect with a significant value of 0.047 which is stated to be smaller than $0.05(0.047<0.05)$ and the number of production factors also has a positive effect on the welfare of shallot farmers, with a significant value of 0.028 which is declared smaller than $00.05(0.028<0.05)$. From these results it can be concluded that the amount of production factor has a significant influence on the welfare of shallot farmers.

The area of agricultural land is a determinant of the influence of agricultural commodities. The total land area in Serading Village is 460 hectares. In a year, shallot farmers harvest 2 times in the 3rd month and 9th month in the dry season because the age of the shallots at 1 harvest is a minimum of 65 days and a maximum of 70 days. In one red onion harvest, farmers can produce a maximum of 17 tons per hectare, depending on climate and weather. Optimal use of land by farmers and the use of quality seed fertilizer, land ownership, and increasing the selling price of shallots can increase the income of shallot farmers (Dinni, 2019).

Production costs are farmers' expenses, namely the production costs of shallots are calculated in rupiah. For production costs incurred from the beginning of harvest to post-harvest for 1 hectare of land planted with shallots in Serading village, it ranges from 100 to 110 million per hectare with a total income of 17 tons with a selling price of 15,000 per kilo of 230 million minus 110 million is 120 million net incomes received by shallot farmers for one time production. Shallot farmers in Serading village always take into account production costs by minimizing production costs incurred such as fertilizer costs, seed costs, pesticide costs, labor costs and so on to get maximum results. The more production costs incurred, the less income received. 
Table 2. Partial Test Results ( $t$ test)

\begin{tabular}{|l|c|c|c|c|c|}
\hline \multirow{2}{*}{ Model } & \multicolumn{2}{|c|}{ Unefficients $^{\mathrm{a}}$} \\
\cline { 2 - 5 } & $\mathrm{B}$ & Std. Error & Beta & & \multirow{2}{*}{ Sig. } \\
\cline { 2 - 5 } & 25,312 & 13,912 & & 6.470 & .000 \\
the day after tomorrow & .115 & .113 & .143 & 1.021 & .012 \\
Production cost & .235 & .116 & .345 & 1.303 & .024 \\
Selling price & .106 & .072 & .216 & 1.475 & .047 \\
Production Quantity & .138 & .033 & .160 & 1.146 & .028 \\
\hline
\end{tabular}

Dependent Variable: Farmer Welfare

The selling price is the total amount of production distributed for the production of shallots. In Serading village the selling price of shallots varies, this depends on the quality of shallots and following market price conditions, it is known that shallot prices always fluctuate. The yield of shallots that have good quality then the selling price is high and when the quality of the onion is not good then the selling price is also low. The high selling price is able to increase the income and welfare of shallot farmers in Serading Village, Moyo Hilir District, Sumbawa Regency. The selling price of shallots in Serading Village 3 months before Eid al-Fitr, there is always an increase in the selling price every year, ranging from 15,000 to 20,000 per kilo of shallots. Setiani (2019) also stated that the development of shallot farming has greater strengths than weaknesses, but there are also major threats when compared to the existing opportunities. This means that the amount of production has a significant effect on the income of shallot farming, if the amount of production produced is small, the income of shallot farming is also small and if the amount of production produced by shallot farmers is large, the results obtained are also large.

\section{CONCLUSION}

The area of agricultural land is a determinant of the influence of agricultural commodities. The total land area in Serading Village is 460 hectares. In a year, shallot farmers harvest 2 times in the 3rd month and 9th month in the dry season because the age of the shallots at 1 harvest is a minimum of 65 days and a maximum of 70 days. In one red onion harvest, farmers can produce a maximum of 17 tons per hectare, depending on climate and weather. This affects the productivity results obtained by shallot farmers in Serading Village. Optimal land use and the use of quality seed fertilizers as well as the high selling price of shallots can increase the income of shallot farmers. The selling price is the total amount of production distributed for the production of shallots. In Serading village the selling price of shallots varies, this depends on the quality of shallots and following market price conditions, it is known that shallot prices always fluctuate. This is what causes the income of shallot farmers in Serading Village is also uncertain. The yield of shallots that have good quality then the selling price is high and when the quality of the shallots is not good then the selling price is also low. For this reason, it is very necessary to develop onion farming by doing proper land management. Before planting shallot seeds, the land must be processed first, after 7 days, then the land is ready to be planted with shallot seeds.

\section{REFERENCES}

[1] Central Bureau of Statistics (BPS). Statistics of Indonesian Seasonal Vegetables and Fruits. Central Bureau of Statistics General Horticulture. 2088-8392. 2017.

[2] Dinni Zahratul. The Effect of Land Area and Farming Capital on the Income of Rubber Farmers in Mudung Laut Village, Serving District, Jambi City. 2019.http://repository.uinjambi.ac.id

[3] Setiani, Rima. "Shallot Development Strategy in Bima Regency, West Nusa Tenggara." Journal of Economics and Development 26(2), 143-52. 2019.https://doi.org/10.14203/JEP.26.2.2018.143152.

[4] Sugiyono. "Combination Research Methods (Mix Methods)." Bandung: Alphabeta. 2015.

[5] Sugiyono. "Quantitative, Qualitative and $R \& D$ Research Methods." Bandung: PT Alfabeta. 2016.

[6] Suratiyah, Ken. "Science of Enterprises revised edition." Jakarta: Self-help spreader. 156 Pg. 2015.

[7] Wiyono, Gendro. "Designing Business research with SPSS 17.0 and SmartPLS 2.0 analysis tools. Yogyakarta: UPP STIM YKPN." 2011 . 